\title{
Estimation of Optimum Water Requirement and Frequency of Watering for Different Tree Seedlings at Bako Agricultural Research Center Nursery Site
}

\author{
Mekonnen Habtemariam Daba ${ }^{*}$, Adisu Eba Tadese \\ Natural Resource Director, Bako Agricultural Research Center, Bako, Ethiopia
}

Email address:

dabanok@gmail.com (M. H. Daba)

${ }^{*}$ Corresponding author

\section{To cite this article:}

Mekonnen Habtemariam Daba, Adisu Eba Tadese. Estimation of Optimum Water Requirement and Frequency of Watering for Different Tree Seedlings at Bako Agricultural Research Center Nursery Site. Journal of Health and Environmental Research.

Vol. 3, No. 6, 2017, pp. 90-97. doi: 10.11648/j.jher.20170306.11

Received: November 27, 2017; Accepted: December 20, 2017; Published: January 11, 2018

\begin{abstract}
Determining water requirement and application frequency of tree seedlings is crucial to use available water effectively. This study estimated the Optimum water requirement and application frequency of tree seedlings: Grevillea robusta, Moringa olifera and Cordia africana at nursery site for the two consecutive years. The experiment was implemented during off-season; because of the objective of the study was to determine amount of water and frequency required for normal growth tree seedlings at nursery stage. Three different water application $(1,1.5$, and 2 liters) and two irrigation frequencies (watering twice daily and watering twice after one day) and the control (Local practices) were combined with tree species. Seeds were sown directly into polythene bags in the traditional nursery site. Different growth parameters were collected and evaluated to estimate the optimum water requirement and watering frequency of different tree seedlings at nursery site. Growth parameters: root collar diameter $(\mathrm{cm})$, height $(\mathrm{cm})$, root depth $(\mathrm{cm})$ and survival rate $(\%)$ were assessed during the nursery stage. The growth parameters measured were subjected to Analysis of Variance (ANOVA). The means were separated by Least Significant Difference (LSD; $\mathrm{P} \leq 0.05)$. The result reveals that significant difference $(\mathrm{P} \leq 0.05)$ was observed among the three tree species growth parameters; root collar diameter, height and survival rate under different watering applications and irrigation frequencies. The average potential evapotranspiration of study area over the two consecutive years were 47 $\mathrm{mm} / \mathrm{month}$. The result indicated that, the growth performance of Moringa olifera and Grevillea robusta were better when watered twice daily with 1.5 liters of per a given plot. The growth performance of Cordia africana was good performed when watered twice after one day with 2 liters of water per a given plot. Also the result showed that Moringa olifera watered twice daily with 1.5 liters had the highest height of $50.74 \mathrm{~cm}$ followed by Moringa olifera watered twice after one day with 2 liters had height of $45.35 \mathrm{~cm}$ and while Grevillea robusta watered twice after one day with 1 liters had the least height $10.73 \mathrm{~cm}$. The study therefore recommends that Moringa olifera and Grevillea robusta seedlings watered twice daily with 1.5 liters and Cordia Africana seedlings watered twice after one day with 2 liters per plot of water availability should be adopted in the area where warm humid climate and high potential evapotranspiration, since it ensures good growth performance of those tree seedlings species.
\end{abstract}

Keywords: Water Requirement, Watering Frequency, Tree Seedling, Growth Parameters, Nursery Site

\section{Introduction}

Water is an important component of plants. Adequate amount of water is critical to successful tree nursery operation among resource-constrained smallholder farmers in Africa [1]. Water requirements of a crop are dependent on the botanical characters of the crop, its stage of growth and the prevailing weather conditions [2]. Water is a significant factor in dry land forestry and it is critical to tree growth and development in the tropics [3]. Detection of crop water stress is critical for efficient irrigation water management, especially in the semi-arid regions. Water is an important 
natural resource that supports life and growth of plants, but there is a growing concern on water availability [4]. With the effects of climate change, water will become increasingly scarce in most geographical zones of the world [5]. Availability of permanent water supply has been one of the major challenges in fruit tree nursery establishment and management, especially in the drier regions of the tropics and sub-tropics. Water use requirements depend on tree species, growth stage and time of the year and hence, it is necessary to establish this for each tree species as there are differences in growth rates [6]. Irrigation implies the application of suitable water to plants in right amount at the right time.

Tree growth parameters are commonly studied to understand the behavior of trees under different nutrient, water or light conditions [7].

The study reported by Luvaha et al. [8], mango seedlings under mild water deficit (watering once or twice in a week) promote growth rate as compared to well watered seedling (watering once or twice daily. Similarly, [9] reported twice weekly watering is most suitable for tending the seedlings of $A$. senegal in the nursery. Establishing optimal water requirements for fruit tree seedlings in the nurseries, promotes sustainable water use [10]. The amount of water required by a crop depends on the local environment, the climate, the crop and its stage of growth, and the degree to which the crop may be stressed [11]. This requirement may be expressed as a uniform depth of water over the area in millimeters per day ( $\mathrm{mm} /$ day).

In Ethiopia, although irrigation has long been practiced at different farm levels, there is no efficient and well managed irrigation water practice. Satisfying crop water requirements, although it maximizes production from the land unit, does not necessarily maximize the return per unit volume of water. Around Bako, although irrigation has long been practiced at different farm levels, there is no efficient and well managed irrigation water practice. There is no information regarding appropriate management of irrigation water and plant water requirement for the rapidly expanding small scale irrigation farms in this area.

Sufficient quantity and quality of water is extremely important for the production tree seedlings at nursery site. This need frequent irrigation and requires careful planning and management, to ensure that operations have sufficient water to maintain adequate supplies for plant production.

Therefore, for effective reforestation or afforestation in degraded areas, it is crucial to understand the water requirements of different tree seedling species. This study estimated the optimal water requirement on the early growth performance of tree seedlings of three tree species commonly used in the area to overcome failuirity of these seedlings due to lack of efficient water management.

\section{Materials and Methods}

\subsection{Description of the Study Area}

This experiment was carried out at nursery site of Bako agricultural research center for the last two consecutive years. The center is located in the western part of Ethiopia at about $9^{\circ} 6^{\prime} \mathrm{N}$ latitude and $37^{\circ} 9^{\prime} \mathrm{E}$ longitudes and a distance of $250 \mathrm{~km}$ away from Addis Ababa at an altitude of $1650 \mathrm{~m}$ above sea level (Figure 1). It has a warm humid climate with annual mean minimum, mean maximum and average temperatures were $13.7,28.3$ and $21^{\circ} \mathrm{C}$ respectively in 1990 2016. The area receives an annual rain fall of $1257.66 \mathrm{~mm}$ with maximum precipitation in the month of June to August (Bako Agricultural Research Center meteorological data record) (Figure 2). The soil of the area is characteristically reddish brown with a $\mathrm{pH}$ that falls in the range of slightly acidic to very acidic (BARC soil laboratory record).

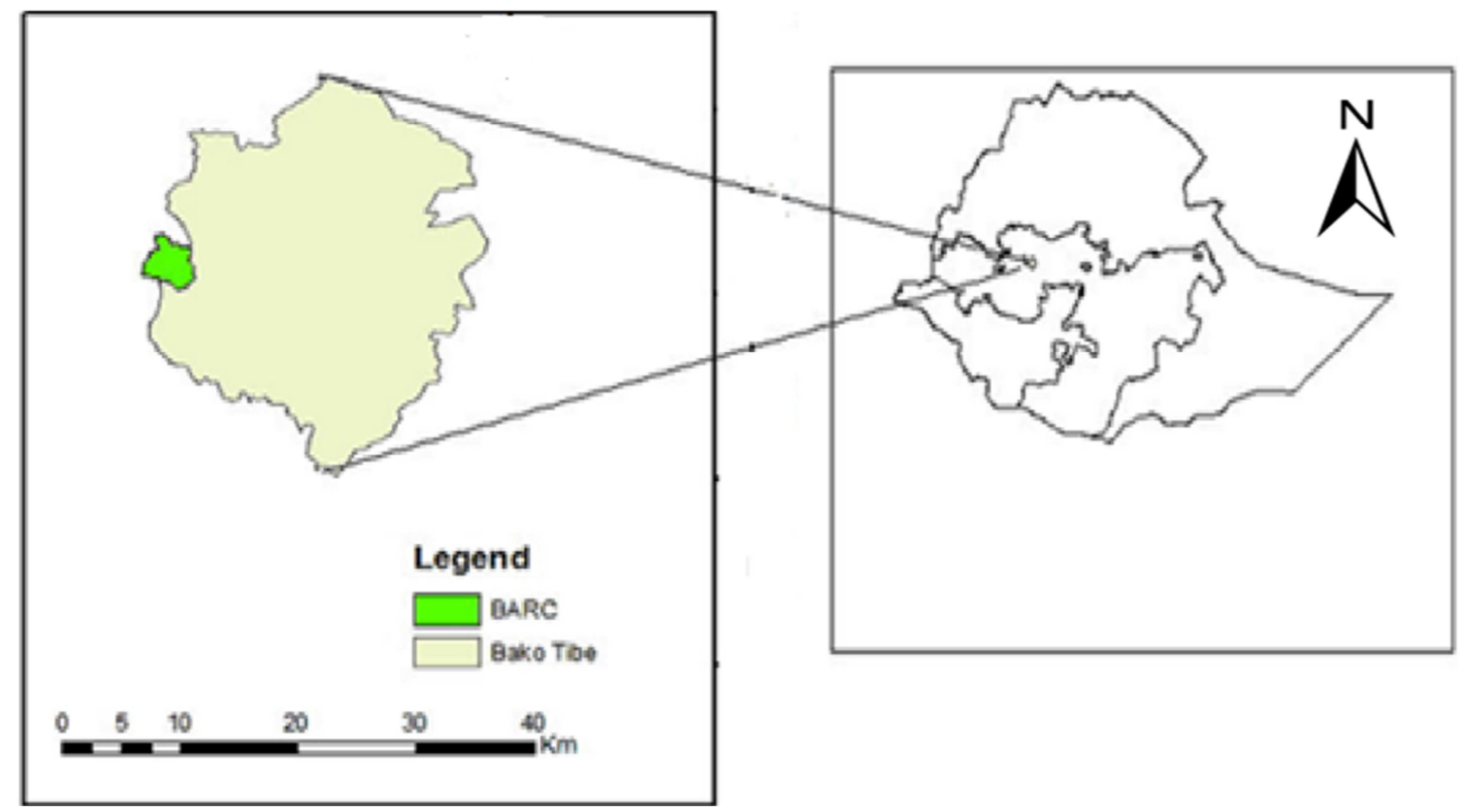

Figure 1. Study area location. 


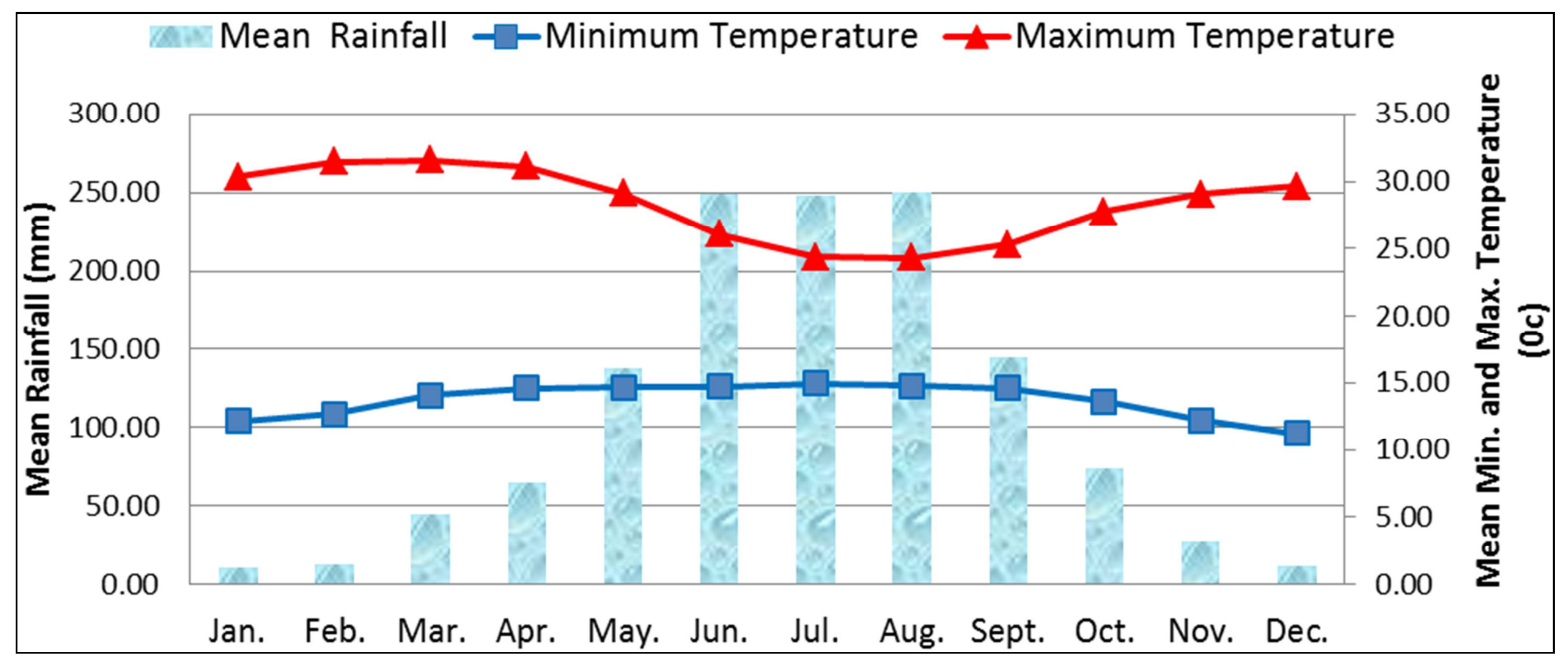

Figure 2. Long-term mean monthly rainfall, minimum and maximum temperature (1990-2016).

\subsection{Experimental Design and Treatments}

Seeds of the three tree species: Grevillea robusta, Moringa olifera and Cordia africana were collected around study area. Grevillea robusta and Moringa olifera seeds were pre-treated with cold water for 24 hours before sowed while Moringa olifera was sowed without any pre-treatment. Pots were prepared from mixture of local soil, forest soil, sand soil, and manure. The pot size of $12 \mathrm{~cm}$ was used for Cordia africana and Moringa olifera, while $10 \mathrm{~cm}$ was used for Grevillea robusta. The nursery bed was prepared on nearly flat land, which has $0.5 \mathrm{~m}$ width and $18.5 \mathrm{~m}$ length including $0.5 \mathrm{~m}$ paths between plots. Surface of bed was leveled by using available material used for land leveling and preparation. Each plot has an area of $1 \mathrm{~m}^{2}$. Depending on the pot size; each plot contains 42 tree seedlings of Grevillea robusta and
Moringa olifera and 36 tree seedlings of Cordia africana.

There were nineteen treatments with three replications. The experiment was conducted in Randomized Complete Block Design (RCBD) with three replications and the treatments are assigned to each plot randomly. Three different water application (1, 1.5, and 2 liters) and two irrigation frequencies (watering twice daily, watering twice after one day) and the control (Local practices) were combined with three tree species (Table 1). Different growth parameters were collected and evaluated to estimate the optimum water requirement and watering frequency of different tree seedlings at nursery site. Growth parameters: root collar diameter, height, root depth and survival rate were assessed during the nursery stage. Destructive sampling was carried for growth parameters assessment.

Table 1. Treatment arrangements.

\begin{tabular}{llll}
\hline & Treatments & Quantities of water (Lit.) & Tree species \\
\cline { 2 - 4 } & Irrigation frequencies & 1 & Cordia africana \\
\hline T1 & Two times per day (M and AF) & 1 & Grevillea robusta \\
T2 & Two times per day (M and AF & 1 & Moringa olifera \\
T3 & Two times per day (M and AF) & 1 & Cordia africana \\
T4 & After one day (M and AF) & 1 & Grevillea robusta \\
T5 & After one day (M and AF) & 1 & Moringa olifera \\
T6 & After one day (M and AF) & 1.5 & Cordia africana \\
T7 & Two times per day (M and AF) & 1.5 & Grevillea robusta \\
T8 & Two times per day (M and AF) & 1.5 & Moringa olifera \\
T9 & Two times per day (M and AF) & 1.5 & Cordia africana \\
T10 & After one day (M and AF) & 1.5 & Grevillea robusta \\
T11 & After one day (M and AF) & 1.5 & Moringa olifera \\
T12 & After one day (M and AF) & 2 & Cordia africana \\
T13 & Two times per day (M and AF) & 2 & Grevillea robus, \\
T14 & Two times per day (M and AF) & 2 & Moringa olifera \\
T15 & Two times per day (M and AF) & 2 & Cordia africana \\
T16 & After one day (M and AF) & 2 & Grevillea robusta \\
T17 & After one day (M and AF) & 2 & Moringa olifera \\
T18 & After one day (M and AF) & Local practice & Cordia, Gravelia and Moringa \\
T19 & Control (Two times per day) &
\end{tabular}

M-Morning; AF- Afternoon; T-Treatment. 


\subsection{Determination of Evapotranspiration (ET)}

Crop water requirements are defined as "the depth of water needed to meet the water loss through evapotranspiration (ET)". Evaporation from an open water surface provides an index of the integrated effect of radiation, air temperature, air humidity and wind on evapotranspiration [11]. However, differences in the water and cropped surface produce significant differences in the water loss from an open water surface and the crop. The pan has proved its practical value and has been used successfully to estimate reference evapotranspiration by observing the evaporation loss from a water surface and applying empirical coefficients to relate pan evaporation to ETo. Evapotranspiration (ETo) can be obtained from:

$$
\mathrm{ETo}=\mathrm{Kp} * \text { Epan }
$$

Where: Kp - Pan Coefficient is 0.75 for pan station located within a distance of crop cover less than $100 \mathrm{~m}$ cropped area, moderate wind speed and medium relative humidity [11].

Epan- pan evaporation in $\mathrm{mm} /$ day.

\subsection{Data Collection}

Determination of potential evaporation was done using a pan evaporation instrument which recorded the amount of water evaporated in a given area of $1 \mathrm{~m}^{2}$ per day. The pan evaporation instrument was placed next to the experiment as shown in (Figure 3). Evaporation is measured daily as the depth of water (in $\mathrm{cm}$ ) evaporates from the pan.

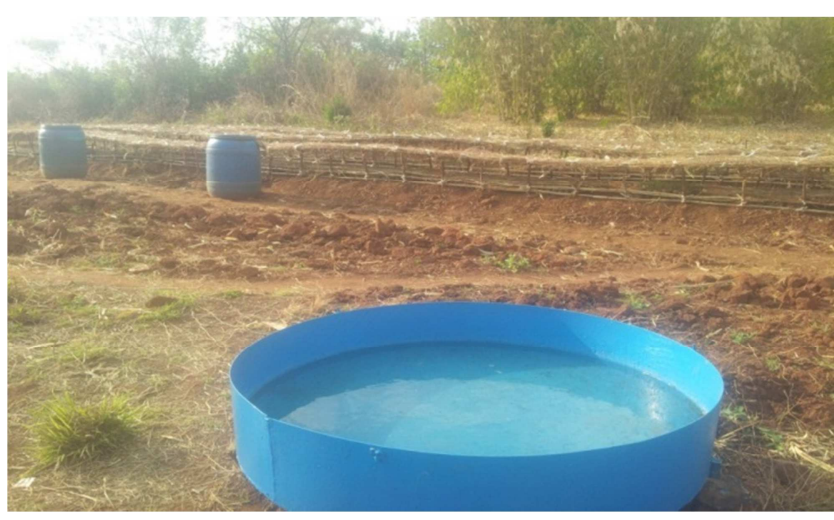

Figure 3. Class pan evaporation.

The experiment was conducted for 12 weeks each year; after which it was terminated for destructive determination of root collar diameter, height and root depth. root collar diameter, height, root depth and survival rate were the growth parameters that were measured for the two consecutive years at its final termination. Tree seedlings in the middle (16 tree seedlings per plot) were taken as a sample for root collar diameter, height and root depth measurement to minimize the border effect, while the survival count was made for the whole trees seedlings in a plot ( 42 tree seedlings per plot for both Grevillea robusta and Moringa olifera and 36 tree seedlings per plot for Cordia africana). Root collar diameter measured by caliper and height and root depth growth was using measuring tapes as shown in (Figure 4).
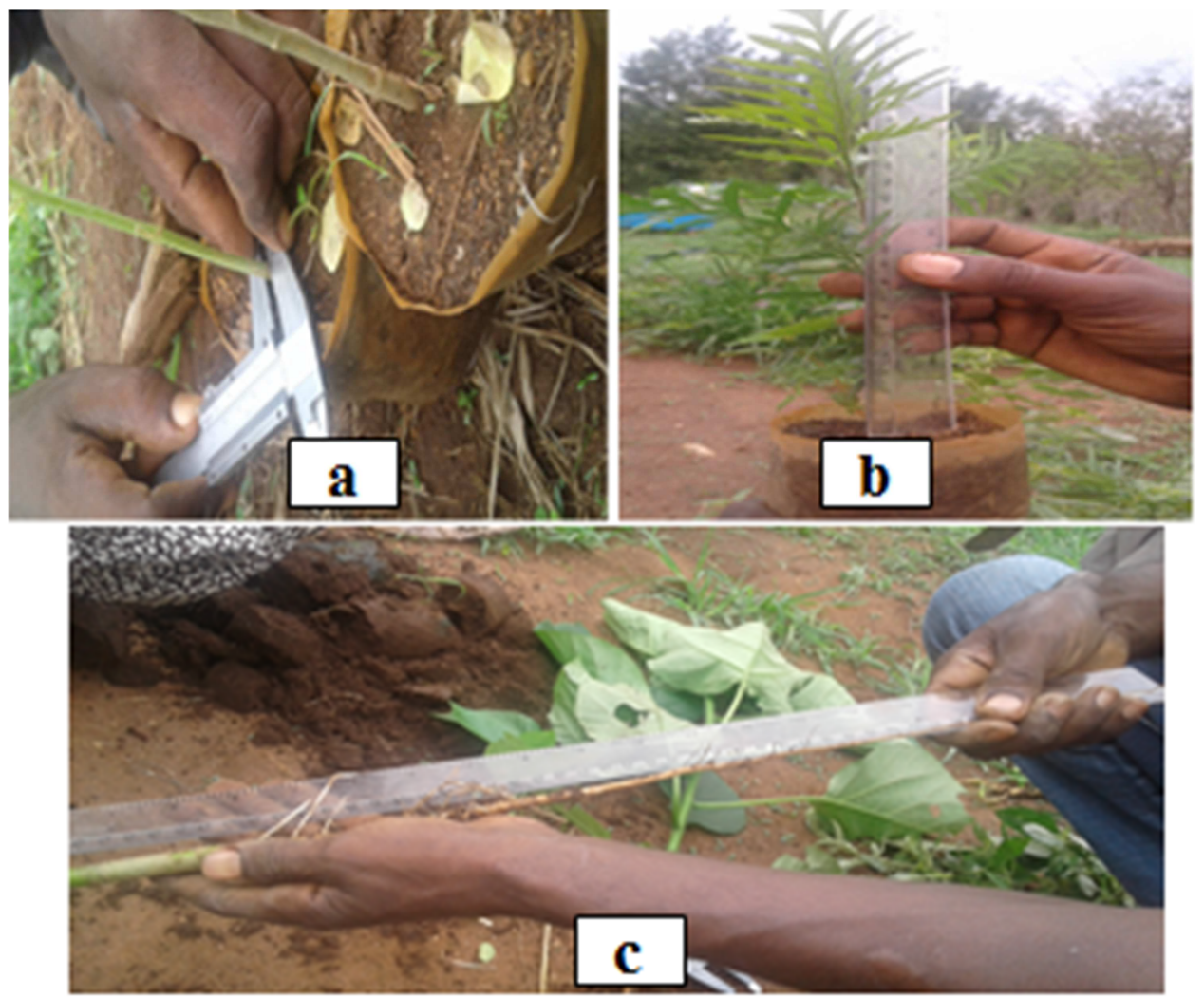

Figure 4. Growth parameters measurements (a-collar diameter, b-height and c-root depth). 


\subsection{Data Analyses}

To compare the effects of the treatments statistical analysis of variance (ANOVA) and general liner model (GLM) was carried out to determine the existence of any statistical difference among the treatments. Separation of significant differences between and among treatment means was made by using statistical analysis system (SAS 9.1 versions). Means was separated using Least Significant Difference (LSD) test.

\section{Results and Discussion}

\subsection{Climatic Condition During the Experimental Period}

The area received minimum rainfall and high temperature during the experimental period. The mean monthly rainfall, minimum and maximum temperature were $20.97 \mathrm{~mm}$, $13.85^{\circ} \mathrm{C}$ and $32.89^{\circ} \mathrm{C}$ respectively during the experimental period (Figure 5). Highest average temperatures of $24.20^{\circ} \mathrm{C}$ was recorded in month of April (end of experimental period) and lowest average temperature of $22.40^{\circ} \mathrm{C}$ was observed in the month of February (mid of experimental period). There was slightly increase in average rainfall towards the end of the experiment. This may be due to the onset of rainfall. The evapotranspiration varied with the time period depending on the atmospheric temperature and other climatic parameters. Pan evaporation was used to measure the amount of water evaporated from open pan to determine the potential evapotranspiration (ETo). The estimated average values of ETo by pan evaporation method in the first and second experimental years were 48 and $46.50 \mathrm{~mm} / \mathrm{month}$ respectively (Figure 6). Based on the collected data, the highest evapotranspiration has been occurred in March and April. This could be due to little rainfall and high temperatures during those months. The average pooled potential evapotranspiration over the two consecutive years were $47 \mathrm{~mm} /$ month.

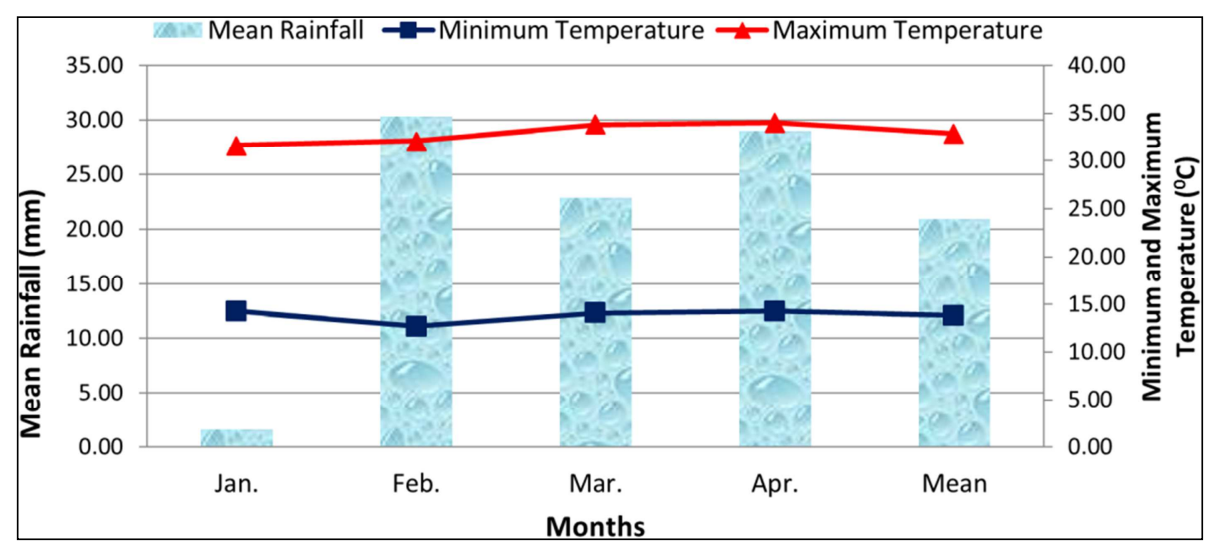

Figure 5. Mean monthly rainfall, minimum, maximum temperature during experimental period.

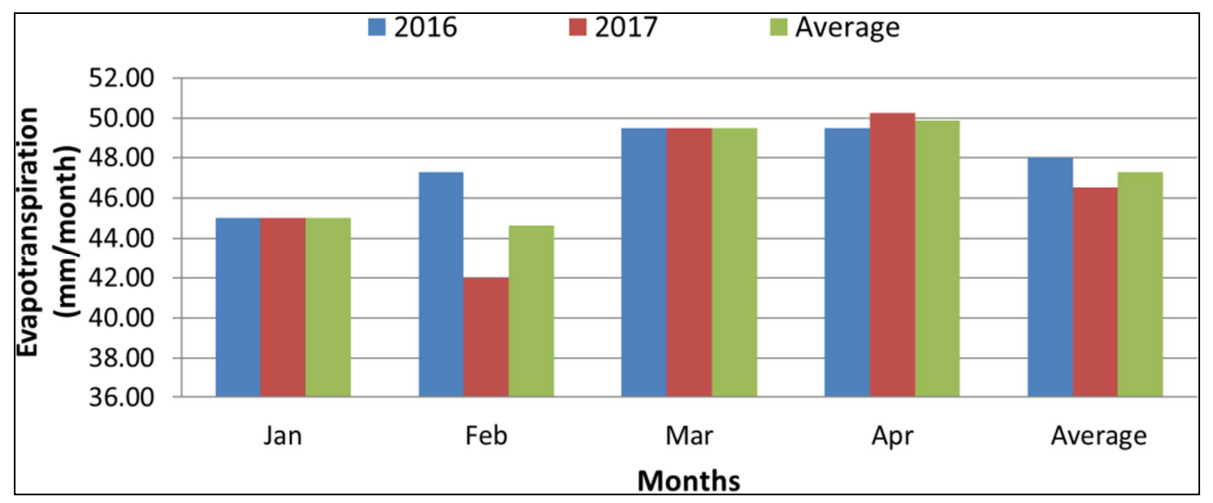

Figure 6. Mean monthly evapotranspiration during experimental period.

\subsection{Tree Seedlings Growth Parameters}

\subsubsection{Seedlings Height}

Significant difference $(\mathrm{P} \leq 0.05)$ was observed among the tree species in root collar diameter due to different watering applications and irrigation frequencies (Table 3). Moringa olifera watered twice daily with $1,1.5$ and 2 liters was not statistically significant in height $(\mathrm{P} \geq 0.05)$ (Table 2$)$. It was observed that Moringa olifera watered twice daily with 1.5 liters, Cordia africana watered twice after one day with 2 liters and Grevillea robusta watered twice daily with 1.5 liters were recorded the highest height $(50.74,33.98$ and $13.53 \mathrm{~cm}$ ) respectively. Moringa olifera watered twice daily with 1.5 liters were produced the tallest height. Moringa olifera watered twice daily with 1.5 liters increased seedling height by $8.86 \mathrm{~cm}$ when compared with a twice after one day with 1.5 liters. Cordia africana watered twice after one day with 2 liters increased seedling height by $11.64 \mathrm{~cm}$ larger 
when compared with a twice after one day with 1 liter. This may shows Cordia africana required optimum water to survive in the humid climate area.

The influence of water quantity and irrigation frequencies were significant $(\mathrm{P} \leq 0.05)$ on the mean height of tree seedlings (Table 3). Moringa olifera and Grevillea robusta watered twice daily with 1.5 liters per plot had the highest mean height value of 50.74 and $13.53 \mathrm{~cm}$ respectively from all irrigation frequencies and amount of water applied. Cordia Africana seedlings watered twice after one day with 2 liters had the highest mean height value of $33.98 \mathrm{~cm}$ from all irrigation frequencies and watering application applied per plot. Similar study showed that Parkia biglobosa plants watered once in five days gave the highest height of the plant [12] and water application of $100 \mathrm{ml}$ per pot at two day interval improves growth in seedling height of P. Americana and V. infausta [1].

Therefore, Moringa olifera and Grevillea robusta seedlings watered twice daily with 1.5 liters; while Cordia africana seedlings watered twice after one day with 2 liters per a given plot were ensures the proper growth mean height of tree species.

Table 2. Summary of analysis of variance of tree seedlings species under different watering applications and irrigation frequencies.

\begin{tabular}{|c|c|c|c|c|c|c|c|c|c|c|c|c|c|}
\hline \multirow{2}{*}{ SV } & \multicolumn{4}{|c|}{ Root collar diameter } & \multicolumn{3}{|l|}{ Height } & \multicolumn{3}{|c|}{ Root depth } & \multicolumn{3}{|c|}{ Survival rate } \\
\hline & df & MS & $\mathbf{F}$ & $\operatorname{Pr}>\mathbf{F}$ & MS & $\mathbf{F}$ & $\operatorname{Pr}>\mathbf{F}$ & MS & $\mathbf{F}$ & $\operatorname{Pr}>\mathbf{F}$ & MS & $\mathbf{F}$ & $\operatorname{Pr}>\mathbf{F}$ \\
\hline TRT & 18 & 0.27 & $14.41 * *$ & $<.0001$ & 1194.7 & $13.87 * *$ & $<.0001$ & 43.10 & $1.24^{\mathrm{ns}}$ & 0.2539 & 229.12 & $9.34 * *$ & $<.0001$ \\
\hline REP & 2 & 0.01 & $0.74^{\mathrm{ns}}$ & 0.4828 & 102.4 & $1.19^{\mathrm{ns}}$ & 0.3105 & 8.15 & $0.23^{\text {ns }}$ & 0.7916 & 50.61 & $2.06^{\mathrm{ns}}$ & 0.1342 \\
\hline YR & 1 & 0.04 & $2.32 \mathrm{n}^{\mathrm{s}}$ & 0.1323 & 1007.78 & $11.7 * *$ & 0.001 & 0.02 & $0^{\mathrm{ns}}$ & 0.9814 & 0.03 & $0^{\mathrm{ns}}$ & 0.9734 \\
\hline TRT*YR & 18 & 0.01 & $0.62^{\mathrm{ns}}$ & 0.8705 & 34.50 & $0.4^{\mathrm{ns}}$ & 0.984 & 42.96 & $1.24^{\mathrm{ns}}$ & 0.2567 & 31.21 & $1.27^{\mathrm{ns}}$ & 0.2308 \\
\hline ERROR & 74 & 0.02 & & & 6375.7 & & & 34.77 & & & 24.52 & & \\
\hline
\end{tabular}

* significantly different at 5\% probability; ns- not significantly different at 5\%; SV- Source of variation; MS- Mean square; F- F value.

\subsubsection{Seedlings Root Collar Diameters}

The effect of different amount of water applied and irrigation frequencies were significant $(\mathrm{P} \leq 0.05)$ on the root collar diameter of seedlings (Table 2). The mean root collar diameter of Grevillea robusta was not significant different in all amount of water applied and irrigation frequencies (Table $3)$. The highest root collar diameter $(0.86 \mathrm{~cm})$ was recorded in Cordia africana watered twice after one day with 2 liters. Similarly, Cordia africana watered twice daily with 1 and 1.5 liters per a given plot were recorded the mean root collar diameter 0.77 and $0.76 \mathrm{~cm}$ respectively. Cordia africana seedlings which received 2 liters of water at irrigation frequency of twice after one day per plot had the highest mean root collar diameters value of $0.86 \mathrm{~cm}$ from all irrigation frequencies and amount of water applied. Treatment $\mathrm{X}$ year interaction were not significantly $(\mathrm{P} \geq$ 0.05 ) different (Table 2). This may be due to similar climate condition and potential evapotranspiration was happened over the last two seasons. Therefore, no separate analysis was required. Similarly the study by Simon et al., [12], concludes that water application of $100 \mathrm{ml}$ per pot at two day interval improves growth in root collar diameter of $P$. americana and $V$. infausta. A similar work carried by Isah et al. [13] indicated that, Acacia Senegal performed better when watered once in three days and this reflects the capability of this species to cope with drought $\mathrm{s}$ tress and Water application of $100 \mathrm{ml}$ every two days was effective in promoting seedlings growth and survival of $P$. americana and V. infausta [1].

Therefore, Moringa olifera and Grevillea robusta seedlings watered twice daily with 1.5 liters while Cordia africana seedlings watered twice after one day with 2 liters per a given plot were ensures the proper growth mean collar diameters of tree species.

\subsubsection{Seedlings Root Depth}

Root depth of seedlings were not significantly different $(\mathrm{P}$ $\geq 0.05$ ) under different amount of water applied and irrigation frequencies (Table 2). It was observed that Cordia africana watered twice after one day with 2 liters, Moringa olifera and Grevillea watered twice after one day with 1.5 liters and Grevillea robusta watered twice after one day with 1.5 liters per plot were recorded the highest root depth $(27.08,23.44$ and $19.57 \mathrm{~cm})$ respectively from all irrigation frequencies and watering application exist. The highest root depth $(27.08 \mathrm{~cm})$ was recorded in Cordia africana watered twice after one day with 2 liters of water. The mean root depth of Grevillea robusta watered twice daily with 1, 1.5 and 2 liters of water was not significant different (Table 3).

\subsubsection{Seedlings Survival Rate}

Similar to height and root collar diameter, significant differences $(\mathrm{P} \leq 0.05)$ was observed among species in survival rate due to different amount of water and irrigation frequencies (Table 2). The mean survival rate of Grevillea robusta watered twice daily with $1,1.5$ and 2 liters and Moringa olifera watered twice daily with 2 liters was not statistically significant $(\mathrm{P} \geq 0.05)$ (Table 3$)$. There was no significant difference $((\mathrm{P} \geq 0.05)$ in survival rate of Cordia africana under all irrigation frequencies and watering applications exists.

The highest survival rate (95\%) was recorded in Grevillea robusta watered twice daily with 2 liters of water. Similarly, Moringa olifera watered twice daily with 1.5 liters and Cordia africana watered twice after one with 1 liters per plot were recorded the highest mean survival rate $93.93 \%$ and $81.40 \%$ respectively from all irrigation frequencies and amount of water applied. 
Table 3. Means of growth parameters of tree seedlings species under different watering applications and irrigation frequencies.

\begin{tabular}{|c|c|c|c|c|}
\hline Treatments & Root collar diameter $(\mathrm{cm})$ & Height (cm) & Root depth (cm) & Survival rate $\%$ \\
\hline $\mathrm{T} 1$ & $0.77^{\mathrm{ab}}$ & $25.50^{\mathrm{efg}}$ & $23.9^{\mathrm{ab}}$ & $80.45^{\mathrm{c}}$ \\
\hline $\mathrm{T} 2$ & $0.27^{\mathrm{f}}$ & $12.17^{\mathrm{hi}}$ & $16.95^{\mathrm{cd}}$ & $94.25^{\mathrm{a}}$ \\
\hline $\mathrm{T} 3$ & $0.69^{\text {bcd }}$ & $48.12^{\mathrm{a}}$ & $20.37^{\mathrm{abcd}}$ & $90.92^{\mathrm{ab}}$ \\
\hline $\mathrm{T} 4$ & $0.64^{\text {bcde }}$ & $22.34^{\mathrm{fgh}}$ & $20.65^{\text {abcd }}$ & $81.38^{\mathrm{c}}$ \\
\hline T5 & $0.25 f$ & $10.73^{\mathrm{i}}$ & $17.22^{\mathrm{bcd}}$ & $87.19^{b}$ \\
\hline T6 & $0.57^{\text {cde }}$ & $36.64^{\mathrm{bcd}}$ & $20.7^{\mathrm{abcd}}$ & $92.29^{\mathrm{ab}}$ \\
\hline $\mathrm{T} 7$ & $0.52^{\mathrm{e}}$ & $16.97^{\text {ghi }}$ & $20.98^{\mathrm{abcd}}$ & $79.03^{c}$ \\
\hline $\mathrm{T} 8$ & $0.28^{\mathrm{f}}$ & $13.53^{\mathrm{hi}}$ & $17.03^{\mathrm{cd}}$ & $92.97^{\mathrm{a}}$ \\
\hline T9 & $0.72^{\mathrm{abc}}$ & $50.74^{\mathrm{a}}$ & $23.44^{\mathrm{abc}}$ & $93.93^{\mathrm{a}}$ \\
\hline $\mathrm{T} 10$ & $0.71^{\mathrm{abcd}}$ & $25.89^{\mathrm{efg}}$ & $21.21^{\mathrm{abcd}}$ & $79.78^{\mathrm{c}}$ \\
\hline $\mathrm{T} 11$ & $0.26^{\mathrm{f}}$ & $12.4^{\mathrm{hi}}$ & $19.57^{\mathrm{bcd}}$ & $90.45^{\mathrm{ab}}$ \\
\hline $\mathrm{T} 12$ & $0.57^{\text {cde }}$ & $41.88^{\mathrm{abc}}$ & $19.62^{\mathrm{bcd}}$ & $91.02^{\mathrm{ab}}$ \\
\hline $\mathrm{T} 13$ & $0.76^{\mathrm{ab}}$ & $26.91^{\operatorname{defg}}$ & $20.68^{\mathrm{abcd}}$ & $77.11^{\mathrm{c}}$ \\
\hline $\mathrm{T} 14$ & $0.27^{\mathrm{f}}$ & $12.73^{\text {hi }}$ & $16.16^{\mathrm{cd}}$ & $95.08^{\mathrm{a}}$ \\
\hline $\mathrm{T} 15$ & $0.72^{\mathrm{abc}}$ & $48.04^{\mathrm{a}}$ & $19.59^{\mathrm{bcd}}$ & $92.872^{\mathrm{ab}}$ \\
\hline $\mathrm{T} 16$ & $0.86^{\mathrm{a}}$ & $33.98^{\text {cde }}$ & $27.08^{\mathrm{a}}$ & $79.65^{\mathrm{c}}$ \\
\hline $\mathrm{T} 17$ & $0.25^{\mathrm{f}}$ & $11.98^{\mathrm{hi}}$ & $18.48^{\mathrm{bcd}}$ & $92.46^{\mathrm{ab}}$ \\
\hline $\mathrm{T} 18$ & $0.64^{\text {bcde }}$ & $45.35^{\mathrm{ab}}$ & $17.93^{\mathrm{bcd}}$ & $91.55^{\mathrm{ab}}$ \\
\hline T19 & $0.56^{\mathrm{de}}$ & $29.3^{\text {def }}$ & $19.28^{\mathrm{bcd}}$ & $89.73^{\mathrm{ab}}$ \\
\hline $\mathrm{CV}$ & 25.13 & 33.66 & 29.12 & 5.70 \\
\hline LSD & 0.16 & 10.7 & 6.71 & 5.77 \\
\hline
\end{tabular}

Means within the same column followed by the same letter not significantly different at $5 \%$ probability level, CV=Coefficient of Variation; LSD $=$ Least Significant Difference.

\section{Conclusions and Recommendations}

Estimation of tree seedlings water requirement and frequency of watering is essential in irrigation scheduling and water resource management. A consistent and adequate source of water supply is essential for all tree seedling nurseries. Variation was found between the three tree seedling species with respect to growth parameters; root collar diameter, height, root depth and survival rate.

Generally, this study concludes that Moringa olifera watered twice daily with 1.5 liters, Cordia africana watered twice after one day with 2 liters and Grevillea robusta watered twice daily with 1.5 liters per plot were ensures good growth performance of those tree seedlings species. Such findings therefore have implications on water wastage, reduced labor costs and maximizing profitability of tree seedlings production at nursery in area where warm humid climate and high potential evapotranspiration.

Therefore, more study is needed for the other species to follow their optimum water requirement and frequency of watering and adaptation under different agro ecological conditions.

\section{Acknowledgements}

The authors are grateful to Oromia Agricultural Research Institute for their financial support to carry out field research.

\section{References}

[1] Simon A., Festus K., Gudeta S., Oluyede C, Betserai I., Ramni J., (2011). Water application rate and frequency affect seedling survival and growth of Vangueria infausta and Persea Americana. African Journal of Biotechnology Vol. 10 (9), pp. 1593-1599.

[2] Farah, S. M. (1996). Water relations and water requirements of wheat. Gezira Research Station Report. P. O. Box 126, Wad Medani, Sudan. P p. 24-36.

[3] Awodol, A. M and Nwoboshi, L. C., (1993). Effect of source of Potassium and frequency of moisture application on growth and macronutrient distribution in seedlings of Parkia biglobosa. Nigerian Journal of Forestry 23 (2).

[4] Goyne PJ, McIntyre GT (2003). Stretching waterQueensland's water use efficiency cotton and grains adoption program. Water SA, 48 (7): 191-196.

[5] Morrison J, Morikawa M, Murphy M, Schulte P (2009). Water scarcity \& climate change: Growing risks for businesses and investors. A Ceres Report, Ceres, Boston.

[6] Bargali K, Tewari A (2004). Growth and water relation parameters in drought-stressed Coriaria nepalensis seedlings. J. Arid Environ. 58: 505-512.

[7] Zahid MD, Nawaz A (2009). Comparative water use efficiency of Eucalyptus camaldulensis and Dalbergia sisso. International J. Agric. Biol. 4, 540-544. 
[8] Luvaha, E; Netondo, G. W. and Ouma, G. 2012. Effect of Water Deficit on the Growth of Mango (Mangifera indica) Rootstock Seedlings. Department of Botany and Horticulture Kisumu, Maseno University, Kenya. pp 2-4pp.

[9] Oyun, M. B; Adeduntan, S. A. and Suberu, S. A. 2010. Influence of watering regime and mycorrhizae inoculations on the physiology and early growth of Acacia senegal (L.) Wild. African Journal of Plant Science Vol. 4 (7): 210216pp.

[10] Mhango J, Akinnifesi FK, Mng'omba SA, Sileshi G (2008). Effect of growing medium on early growth and survival of Uapaca kirkiana Müell Arg. seedlings in Malawi. Afr. J. Biotechnol. 7 (13): 2197-2202.

[11] Doorenbos, Pruitt W, Aboukhaled A., Damagnez J., Dastane N. G., Berg C., Rijtema P. E.., Ashford O. M., Frere M.,
(1992). Crop Water Requirements. FAO Irrigation and Drainage paper 24.

[12] Sale, F. A., (2015) Evaluation of watering regimes and different pot sizes in the growth of Parkia biglobosa (jacq) benth seedlings under nursery condition. Euro. Scien. Journal $11(12)$.

[13] Isah, A. D., Bello, A. G., Maishanu, H. M and Abdullahi, S. (2013): Effect of Watering Regime on the Early Growth of Acacia Senegal (LINN) Willd. Provenances. International Journal of Plant, Animal and Environmental Sciences. Vol 3: 2 -9. Teresa A., Mike K., Kelly L., Michael J., (2002). Efficient Irrigation of Trees and Shrubs. Utah State University. (EP/0602/DF). 